\title{
Impact of Palm Oil versus Other Oils on Weight Changes: A Systematic Review
}

\author{
Nor Asiah Muhamad1,2*, Normi Mustapha3 ${ }^{3}$ Mohd Farid Baharin', Mohd Hatta Abdul Mutalip1, \\ Murnilina Abdul Malek ${ }^{5}$, Ruhaya Salleh1, Nor Azian Mohd Zaki1, Fatimah Othman1, Tahir Aris', \\ Shahnaz Murad 6
}

\author{
${ }^{1}$ Institute for Public Health, Ministry of Health, Kuala Lumpur, Malaysia \\ ${ }^{2}$ Non-Communicable Disease Section, Ministry of Health, Putrajaya, Malaysia \\ ${ }^{3}$ Faculty of Science and Technology, Open University, Kuala Lumpur, Malaysia \\ ${ }^{4}$ Institute for Medical Research, Ministry of Health, Kuala Lumpur, Malaysia \\ ${ }^{5}$ Clinical Research Centre, Hospital Kuala Lumpur, Ministry of Health, Kuala Lumpur, Malaysia \\ ${ }^{6}$ Office of Deputy Director General of Health (Research and Technical), Ministry of Health, Putrajaya, Malaysia \\ Email: *norasiahdr@gmail.com
}

How to cite this paper: Muhamad, N.A., Mustapha, N., Baharin, M.F., Mutalip, M.H.A., Malek, M.A., Salleh, R., Zaki, N.A.M., Othman, F., Aris, T. and Murad, S. (2018) Impact of Palm Oil versus Other Oils on Weight Changes: A Systematic Review. Food and Nutrition Sciences, 9, 915-936.

https://doi.org/10.4236/fns.2018.97068

Received: June 6, 2018

Accepted: July 28, 2018

Published: July 31, 2018

Copyright $\odot 2018$ by authors and Scientific Research Publishing Inc. This work is licensed under the Creative Commons Attribution International License (CC BY 4.0).

http://creativecommons.org/licenses/by/4.0/ (c) (i) Open Access

\begin{abstract}
Objective: The present review aimed to determine the effect of palm oil versus other oils on changes in body weight or Body Mass Index (BMI). Design: A systematic review was conducted. Studies were identified by database searching (EMBASE, PUBMED, CENTRAL, SCOPUS, PROQUEST, Web of Science [ISI Web of Knowledge], Cumulative Index to Nursing and Allied Health Library (CINAHL Plus), LILAC and ClinicalTrials.gov. Searching, selecting and reporting were done according to the PRISMA (Preferred Reporting Items for Systematic reviews and Meta-Analyses) Statement. Setting: Palm oil vs other oils intervention study on weight or BMI changes. Subjects: Individuals participating in palm oil vs other oil intervention study. Results: A total of 182 studies were screened for eligibility, five studies were finally included. Three studies compared the effect of palm oil vs sunflower oil on weight changes and BMI. One study examined the effect of hybrid palm oil vs extra virgin olive oil on weight changes. The last study examined the effect of palm oil vs olive oil vs lard on weight changes. Out of 292 participants in five studies, only one study (Iggman, 2014) had a low risk of bias. In this study, there was no significant difference between the group that received sunflower oil and palm oil (SMD: $0.04,95 \%$ CI: -0.59 to 0.66 ). Other four studies had unclear risk of bias. Conclusions: Based on the review, there is insufficient evidence to suggest the impact of palm oil intake on weight changes or BMI.
\end{abstract}

\section{Keywords}

Palm Oil, Systematic Review 


\section{Introduction}

\subsection{Description of the Condition}

Obesity is an epidemic which is worsening in most parts of the world and a major health concern in Malaysia that recorded an increment for the last 20 years [1] [2]. Obesity is defined as a condition of excess adiposity and physiological state occurs in chronic imbalance of whole-body energy metabolism that caloric intake exceeding the energy expenditure [3]. Global Health Observatory Data by WHO also recorded a doubling in the prevalence of obesity from 1980-2014 where in 2014, more than 1.9 billion adults aged 18 years and older were overweight, out of which over 600 million adults were obese [4]. Additionally, according to Snodgrass et al. (2016) adults are progressing from being overweight to being obese or morbidly obese at alarming rates [5].

Evidences have shown the effect of increase in body weight or BMI are associated with the risk of chronic diseases such cardio vascular disease (CVD), type 2 diabetes mellitus (T2DM), hypertension, stroke, and some type of cancers [6] [7] [8]. Report from Malaysian National Health and Morbidity Survey (NHMS) shows an increasing trend in the percentage of overweight and obese individuals in the country from 1996 to 2002-2003 where the prevalence of obesity was more than doubled and that the number of adults overweight increased more than $60 \%$ [9]. Changes in the life style and dietary fat consumption may result in endocrine disorders [10]. Studies have shown a strong positive association between saturated fat intake and the development of obesity and CVD [7] [8] [11].

Saturated fats such as myristic, palmitic and lauric have been reported to cause disadvantages to health compared with the shorter chain saturated fats and unsaturated fatty acid such as oleic acid [12] [13]. Two types of oils that are produced by oil palms are palm kernel oil and palm oil, which nowadays are important in world trade. Palm oil which is obtained from the mesocarp of the palm fruit is composed of $50 \%$ saturated fatty acids, $40 \%$ monounsaturated fatty acids and $10 \%$ polyunsaturated fatty acids. The saturated fatty acid to unsaturated fatty acid ratio of palm oil is close to unity and it contains a high amount of the antioxidants, $\beta$-carotene, and vitamin $\mathrm{E}$ [13].

Palm oil is claimed to have high saturated fat and its consumption supposedly raises the levels of blood cholesterol, thereby increasing the risk of coronary heart disease as well as obesity [14]. Based on individual studies, it is difficult to clearly determine if palm oil consumption is directly associated to overweight and/or obesity, as obesity is likely to be multifactorial, with factors such as other dietary habits, level of activity as well as lifestyle playing important parts.

\subsection{Quality and Performance of Palm Oil}

Food manufacturers prefer palm oil because of its nutritional benefits and versatility. The oil is highly structured to contain more than $95 \%$ neutral triacylglycerols (TAGs, or triglycerides) and less than $0.5 \%$ free fatty acids (FFAs). The 
quality and nutritional benefits have been assured for the variety of foods that can be manufactured from the oil directly or from blends with other oils while remaining trans-free [15].

Their resistance to two major chemical reactions i.e. hydrolysis and oxidation will determine their quality. The hydrolysis reaction occurs slowly in the presence of water but is catalysed by lipase enzymes as well as acid whereas oxidation is mediated by initiating free radicals to produce more radicals from fat molecules, which then readily combine with oxygen, a diradical (O-O), of air to give hydroperoxy radicals and then hydroperoxides. The role of fats in health and nutrition should be evaluated in the context of the digestion, absorption, and metabolism of lipids.

Triacylglycerols with long-chain fatty acids are mainly hydrolyzed by the pancreatic lipase to 2-monoacylglycerols or 2-monoglycerides and free fatty acids from positions -1 and -3 of the triglycerides as shown in Figure 1. The ease or difficulty of absorption of these components will affect their subsequent metabolism and finally their role, if any, in cardiovascular diseases.

Fatty acids in the 2-monoacylglycerols are mainly unsaturated (87\%), although overall $50 \%$ of the fatty acids in the three positions of triacylglycerols are saturated, a consequence of having the 1- and 3-positional fatty acids more highly saturated. There are two very important dietary consequences. First, the absorbed fatty acids are mainly mono- and di-unsaturated (87\% for palm oil and up to $96 \%$ for palm olein), despite the relatively high saturation in the total glycerides.. Assuming that all the unsaturated fatty acids at the 1- and 3-positions in palm oil are preferentially absorbed while the saturated fatty acids from these same positions are excreted as salts, then only $8 \%$ of saturated fatty acids from the 2-position will be absorbed, an ideal situation to enhance the nutritional attribute of palm oil.

All oils and fats have the triacylglycerol or triglyceride structures shown below. Their differences were on the types of fatty acids ( $\mathrm{RCOOH})$ attached to the glycerol backbone in positions 1,2 , and 3 [16].

There are many hypotheses linking palm oil and increase in weight or BMI. This review aims at synthesising the available evidence reporting the effect of palm oil consumption with weight changes or BMI including obesity specifically or any other anthropometric measurements.<smiles>[R]OC[C@@H](OC([R])=O)C([2H])COO[R]</smiles>

\section{Triacylglycerol (TAG) or Triglyceride}<smiles>[R]OO[C@H]([3H])[C@H](O)CO[R]([H])=O</smiles>

\section{1,3-Diacylglycerol} (DAG)<smiles>[R]C(=O)OC(CO)CO</smiles>

2-Monoacylglycerol (MAG)

Figure 1. Types of fatty acids. 


\section{Methodology}

This systematic review was conducted based on Cochrane Handbook for Systematic Reviews of Interventions guidelines and Strengthening the Reporting of Observational Studies in Epidemiology (STROBE) [17] [18]. Preferred Reporting Items for Systematic Reviews and Meta-Analyses (PRISMA) guidelines were followed in conducting and reporting the results of this systematic review and meta-analysis [19].

\subsection{Search Strategy}

A search strategy was developed to identify studies for this review. The search strategy contained population terms, exposure terms and outcome terms. The search terms included thesaurus terms or Medical Subject Headings (MeSH) as well as title and abstract text searches.

An electronic search for eligible papers were conducted in April 2018 from their earliest record up to $3^{\text {rd }}$ April 2018; Medline, EMBASE, PsychINFO, Web of Science [ISI Web of Knowledge], Cumulative Index to Nursing and Allied Health Library (CINAHL) [Ebscohost], SCOPUS, LILAC and The Cochrane Library. The search strategy was developed in Medline (Appendix 1) prior to adaptation for the other databases. A grey literature search for unpublished and continuing research was undertaken in March 2018. Search in the metaRegister of Controlled Trials, Clinical Trials.gov (www.clinicaltrials.gov) were also conducted up to $3^{\text {rd }}$ April 2018. The following search term was used "palm oil or related word variation" and "obesity or related word variation" (pre-obese, body mass index, body weight, waist circumference) or anthropometry wherever available. The references of included studies and systematic reviews were inspected for any additional studies.

\subsection{Type of Studies}

If we could find studies that assessed the effect of palm oil consumption to weight changes or BMI, particularly in large national or regional-level cohort studies, we would include these studies in the review, as well as any study that evaluated the effects of palm oil consumption to weight changes in human, such as randomized controlled trials, cluster-randomized controlled trials and quasirandomized controlled trials and all types of observational studies without any languages restriction. All studies that did not use palm oil as an exposure or any animal studies were excluded in this review.

We planned to include studies that use incidence or prevalence of obesity as outcome according to the definition of World Health Organization (WHO) as primary outcome measure. Overweight and obesity is also defined as abnormal or excessive fat accumulation that may impair health (WHO, 2017) [20]. BMI is a simple index of weight-for-height that is commonly used to classify overweight and obesity in adults. Additionally, as obesity can be measured indirectly as increase in body weight, changes in body mass index and changes in body fat 
measurement were also included. No limitations concerning publication date, disease course of participants, or language were made. We planned to include all adults and children of both sexes in this review. We screened all exposures by looking at the effect of dietary palm oil versus any other oils on obesity.

\subsection{Data Collection and Analysis}

\subsubsection{Selection of Studies}

Two authors independently screened all the titles and abstract to identify eligibility. Search results were combined using a reference management software (EndNote) and all duplicates were removed. The resulting titles/abstracts were coded as include/exclude/unsure. Discrepancies were resolved by discussion and the third author decided on final decision. Selection process was recorded in a PRISMA diagram shown in Figure 2 and a table describing the characteristics of the included studies were constructed. The full texts of all potentially eligible articles were retrieved for independent review. Any disagreements were resolved by discussion. Articles deemed eligible went on to data extraction and quality assessment. Reviewers were not blinded to study authors.

\subsubsection{Data Extraction and Management}

Data extraction was performed according to a standardized data extraction form. We developed a "Participants", "Exposure," "Comparator", "Outcomes" and "Methods" (PECOM) statement as follows: 1) Participants: N, mean age or age range, gender, diagnostic criteria if applicable, inclusion criteria and exclusion criteria, 2) Exposures: description of exposure, duration, intensity, content of exposure, and other similar exposure 3) Comparator: what type of other oils that was used as comparison 4) Outcomes: description of primary and secondary outcomes specified and collected, and time points reported, 5) Methods: study design, total duration of study, study location, study setting, withdrawals and study period.

\subsection{Assessment of Risk of Bias in Included Studies}

\section{Risk of Bias Assessment}

We used the Cochrane Risk of Bias tool to assess study quality. The risk of bias assessment was performed by two review authors. Any disagreements were resolved by another author. The risk of bias was made base on these domains:

- Random sequence generation.

- Allocation concealment.

- Blinding of participants and personnel.

- Blinding of outcome assessment.

- Incomplete outcome data.

- Selective outcome reporting.

- Other bias.

Each potential source of bias was graded as high, low or unclear. We used the specific evidence grading system developed by the GRADE group to assess the study quality [21]. 


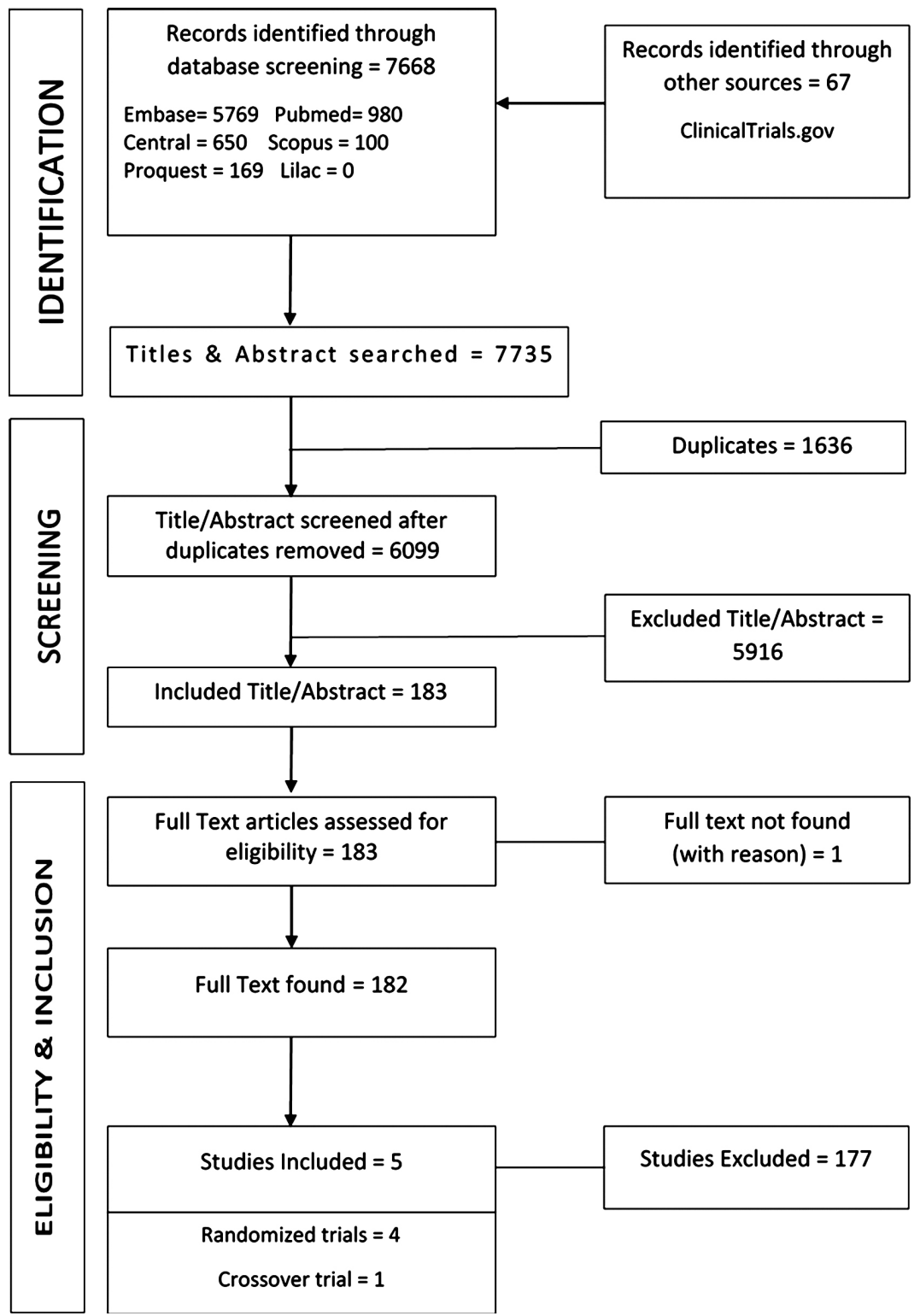

Figure 2. Prism Flowchart.

\subsection{Data Synthesis}

We performed meta-analyses using Review Manager 5.3 (RevMan 2013) [22]. We followed the recommendations as stated in the Cochrane Handbook for Systematic Review of Interventions [23] [24]. If we had found any numerical outcome data that were missing, such as standard deviations or correlation coefficients, and they could not be obtained from the authors, we would have calculated them from other available statistics such as $\mathrm{P}$ values according to the methods described in the Cochrane Handbook for Systematic Reviews of Interventions [23] [24] [25]. We created a summary of findings (SOF) table according to the Cochrane Handbook of Systematic Reviews of Interventions [26]. We chose three major outcomes to be included in our SOF table, which was generated using the GRADEpro software [27]. We expressed our results as MD or SMD. 


\section{Results}

A total of 7735 articles were retrieved from the database searches. Of these, 6099 unique articles were screened for title and abstracts. Following selection based on titles and abstracts, only 183 articles were eligible for full text-review. Searching clinicaltrials.gov yielded no additional studies. Cross-reference examination also yielded no additional relevant articles. Only one article was identified as a crossover trial i.e. study done by Tholstrup et al. 2011 [28]. The remaining 4 articles were randomised controlled trial. Therefore, a total of five articles were considered for quality assessment.

\subsection{Excluded Studies}

A total of 177 studies were excluded from the analysis. We excluded 70 studies that did not measure directly or indirectly the outcome of interest, 33 studies that did not use palm oil or its derivatives as the intervention, 27 animal or in-vitro studies, 46 conference and commentary papers. We also excluded 1 studies that only measured palm oil without any comparator.

\subsection{Included Studies}

\section{Characteristics of Included Studies}

Out of the five included studies, four were RCTs, and one was quasi-randomised, cross-over study. Studies were conducted between 2005 to 2015 in Sweden, Denmark, Colombia and two studies were done in USA. All studies involved healthy adults of both sexes except study performed by Tholstrup et al. (2011) which included only adult men as their participants [28]. We defined the criterion as having been met if the study used palm oil in the intervention with a different list of comparisons. For example, study done by Kien 2005, the intervention is on high palmitic acid compared to high oleic acid from sunflower oil [29]. Whereas another four studies i.e. Tholstrup et al. 2011 between palm olein compared to olive oil and lard [28]; Iggman 2014 between palm oil rich in saturated fatty acid compared to sunflower oil rich in polyunsaturated fatty acid [30]; Kien 2014 between high palmitic acid (source from palm oil 89\%, peanut oil $6.75 \%$, olive oil $4.25 \%$ ) compared low palmitic acid with high oleic acid (source from sunflower oil 19.3\%, hazelnut oil 43.8\%, palm oil 36.9\%) [31] and lastly study done by Lucci et al. 2015 that compared between rich extra-virgin olive oil (EVOO) diet and hybrid palm oil-rich (HPO) diet.

All studies either assessed weight and/or BMI as the primary outcomes, and none of the studies assessed incidence or prevalence of obesity. Detailed description of study characteristics is depicted in Table 1.

\section{Overall Search Results}

\subsection{Risk of Bias of the Included Studies}

Only study done by Iggman 2014 was considered to have low risks of bias across all domains [30]. 
Table 1. Characteristics of included studies.

\begin{tabular}{|c|c|c|c|c|c|c|}
\hline & Method & Participant & Intervention & $\begin{array}{c}\text { Main } \\
\text { outcome } \\
\text { measure }\end{array}$ & Main finding & Notes \\
\hline $\begin{array}{l}\text { Iggman } \\
2014\end{array}$ & $\begin{array}{l}\text { Randomised control } \\
\text { trial } \\
\text { Double-blinded } \\
\text { Parallel group } \\
\text { Period of study: } 5 \\
\text { months }\end{array}$ & $\begin{array}{l}39 \text { healthy lean } \\
\text { individuals with } \\
\text { mean age of } 27 \pm 4 \\
\text { years }\end{array}$ & $\begin{array}{l}\text { Palm oil rich in } \\
\text { saturated fatty acid vs } \\
\text { sunflower oil rich in } \\
\text { polyunsaturated fatty } \\
\text { acid }\end{array}$ & $\begin{array}{l}\text { weight } \\
\text { gain }(\mathrm{kg})\end{array}$ & $\begin{array}{l}\text { small difference in body } \\
\text { weight changes between } \\
\text { the group that received } \\
\text { palm oil and sunflower } \\
\text { oil [mean difference } \\
-0.56 \text { ( } 95 \% \text { CI }-1.20 \text { to } \\
0.08) \text { ] }\end{array}$ & $\begin{array}{l}\text { study was carried out for } \\
7 \text { weeks between August- } \\
\text { December } 2011 \text { in } \\
\text { Sweden }\end{array}$ \\
\hline Kien 2005 & $\begin{array}{l}\text { Randomised Control } \\
\text { Trial } \\
\text { Double-blinded } \\
\text { Period of study: } 8 \\
\text { weeks }\end{array}$ & $\begin{array}{l}43 \text { healthy, } \\
\text { non-obese young } \\
\text { adults } \\
(21-34 \text { years old) }\end{array}$ & $\begin{array}{l}\text { High Palmitic Acid } \\
\text { (source from palm oil) } \\
\text { vs High Oleic Acid } \\
\text { (source from sunflower } \\
\text { oil) }\end{array}$ & BMI & $\begin{array}{l}\text { no difference in BMI } \\
\text { changes for both men } \\
\text { and women who } \\
\text { received palm oil and } \\
\text { sunflower oil [mean } \\
\text { difference }-0.20 \text { ( } 95 \% \\
\text { CI }-2.01 \text { to } 1.61)\end{array}$ & $\begin{array}{l}\text { Conducted in Ohio State } \\
\text { University medical } \\
\text { Centre, United States }\end{array}$ \\
\hline Kien 2014 & $\begin{array}{l}\square \text { Quasi-randomized, } \\
\text { cross-over clinical } \\
\text { trial } \\
\text { Period of study: } 29 \\
\text { days }\end{array}$ & 9 men and 9 women & $\begin{array}{l}\text { High palmitic acid } \\
\text { (source from palm oil } \\
89 \% \text {, peanut oil } 6.75 \% \text {, } \\
\text { olive oil } 4.25 \% \text { ) vs low } \\
\text { palmitic acid with high } \\
\text { oleic acid (source from } \\
\text { sunflower oil } 19.3 \% \text {, } \\
\text { hazelnut oil } 43.8 \% \text {, } \\
\text { palm oil } 36.9 \% \text { ) }\end{array}$ & $\begin{array}{l}\text { Body } \\
\text { weight } \\
\text { BMI } \\
(\mathrm{kg})\end{array}$ & $\begin{array}{l}\text { small difference for } \\
\text { changes in body weight } \\
\text { for men [mean } \\
\text { difference } 0.01 \text { ( } 95 \% \text { CI } \\
-0.91 \text { to } 0.93) \text { ] and } \\
\text { women }[0.01(95 \% \mathrm{CI} \\
-0.92 \text { to } 0.93)] \\
\text { respectively }\end{array}$ & $\begin{array}{l}\text { Study conducted in } \\
\text { University of Vermont, } \\
\text { United States. } \\
\text { This oil was not used for } \\
\text { cooking (as cooking oil) } \\
\text { but was added with food } \\
\text { that has been warmed }\end{array}$ \\
\hline $\begin{array}{l}\text { Lucci, } \\
2015\end{array}$ & $\begin{array}{l}\square \text { Randomised control } \\
\text { trial } \\
\text { Period of study: } 3 \\
\text { months }\end{array}$ & $\begin{array}{l}160 \text { Eligible } \\
\text { participants were } \\
\text { community-dwelling } \\
\text { men and women, } \\
\text { aged } \geq 50 \text { years. }\end{array}$ & $\begin{array}{l}\text { Rich extra-virgin olive } \\
\text { oil }(\text { EVOO) diet }(\mathrm{n}= \\
\text { 82) or hybrid palm } \\
\text { oil-rich } \\
\text { (HPO) diet }(\mathrm{n}=78)\end{array}$ & BMI & $\begin{array}{l}\text { no difference in BMI } \\
\text { changes between the } \\
\text { group that received } \\
\text { hybrid palm oil and } \\
\text { extra virgin olive oil, } \\
\text { mean difference } 0.60 \text {, } \\
\text { (95\% CI }-0.55 \text { to } 1.75 \text { ) }\end{array}$ & Study location Colombia \\
\hline $\begin{array}{l}\text { Tholstrup } \\
2011\end{array}$ & $\begin{array}{l}\text { Randomized } \\
\text { Controlled } \\
\text { Double-blinded } \\
\text { Period of study } 3 \times 3 \\
\text { weeks crossover dietary } \\
\text { intervention (without } \\
\text { washout period) }\end{array}$ & $\begin{array}{l}32 \text { healthy men } \\
\text { (19-64 years old) }\end{array}$ & $\begin{array}{l}\text { palm olein vs olive oil } \\
\text { vs lard }\end{array}$ & $\begin{array}{l}\text { weight } \\
(\mathrm{kg})\end{array}$ & $\begin{array}{l}\text { no difference in body } \\
\text { weight changes between } \\
\text { the groups that received } \\
\text { palm oil and olive oil } \\
\text { [mean difference }-0.30 \text {, } \\
95 \% \text { CI }(4.56 \text { to } 3.96 \text { ) }\end{array}$ & $\begin{array}{l}\text { study carried out in } \\
\text { collaboration between } \\
\text { MPOB and Department } \\
\text { of Human Nutrition, } \\
\text { Faculty of Life Sciences } \\
\text { University of } \\
\text { Copenhagen, Denmark }\end{array}$ \\
\hline
\end{tabular}

Risk of bias profiles of the remaining studies were unclear in most domains due to insufficient information provided by the authors. A detailed risk of bias assessment, displayed at the domain level and the study level, and are available in Figure 3 and Figure 4 respectively.

\subsection{Analysis of Included Studies.}

\subsubsection{Analysis 1}

Based on one study, Lucci et al., there was no difference in BMI changes between the group that received hybrid palm oil and extra virgin olive oil, mean 


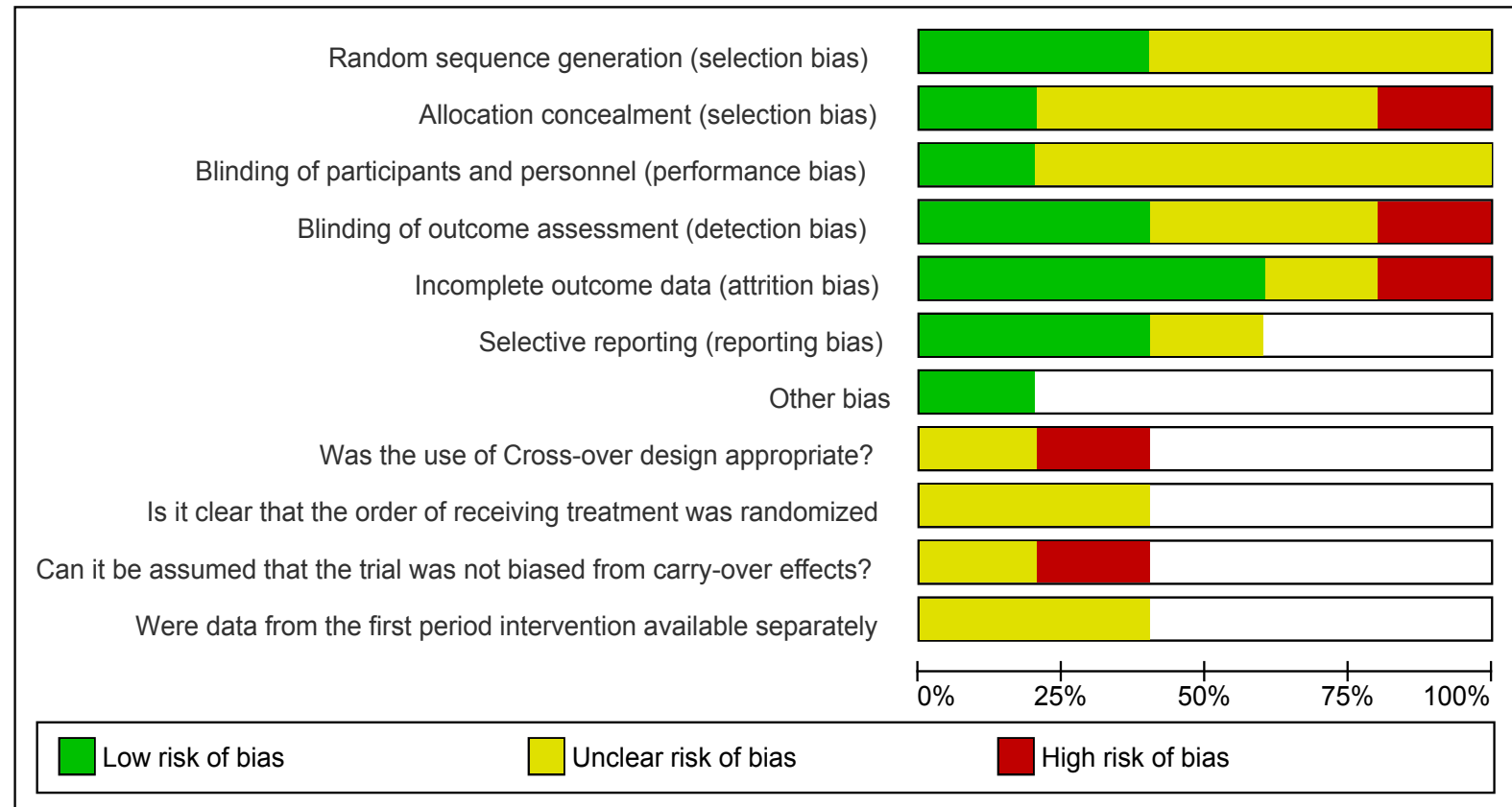

Figure 3. Risk of bias graph: review authors' judgements about each risk of bias item presented as percentages for each included study.

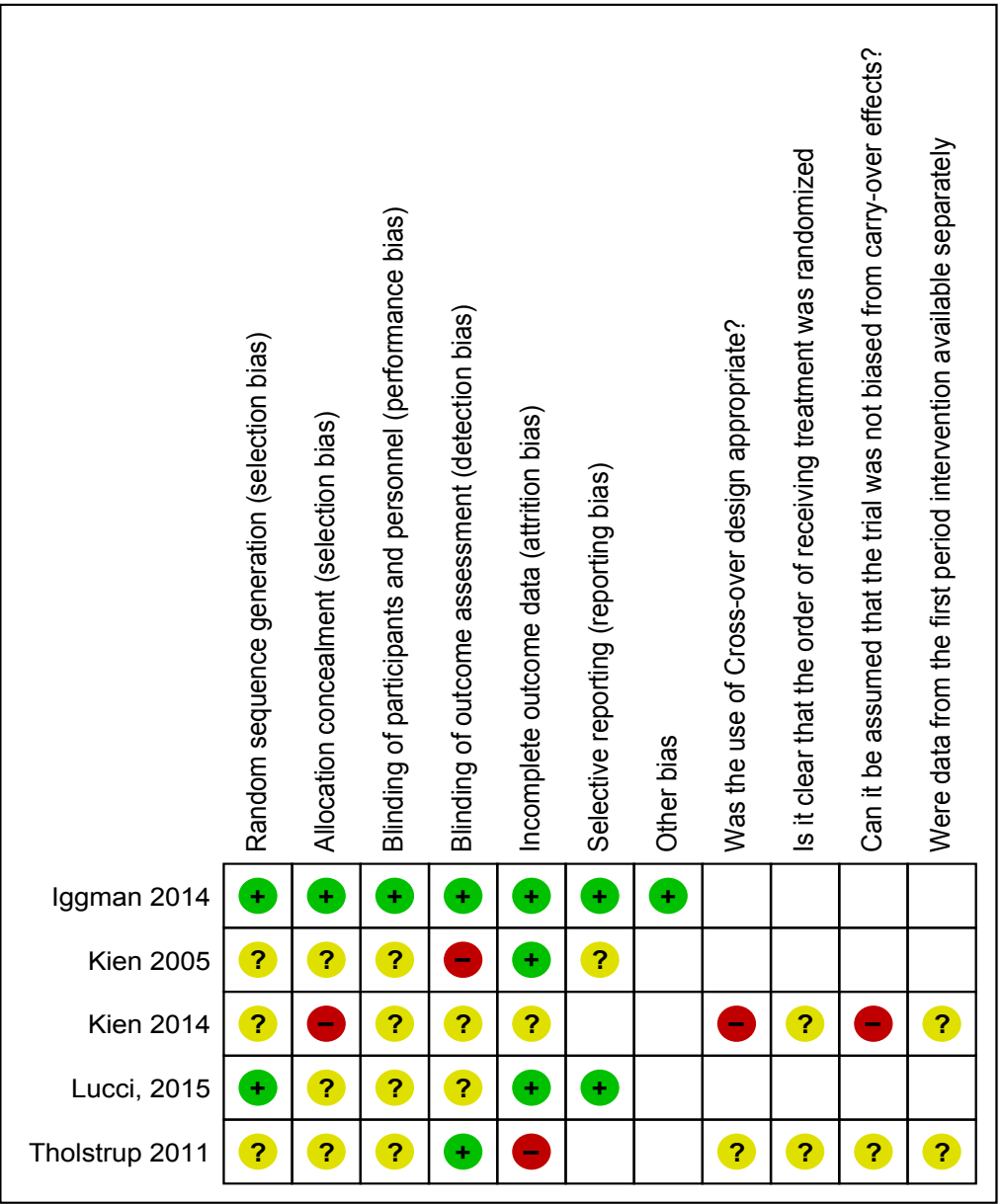

Figure 4. Risk of bias summary: review authors' judgements about each risk of bias item for each included study. 
difference 0.60 , (95\% CI -0.55 to 1.75 ) with low quality of evidence, downgraded for high risk of bias and small study as shown in Figure 5 and Table A1 [32].

\subsubsection{Analysis 2}

Based on one study (Iggman 2014), there was a small difference in body weight changes between the group that received palm oil and sunflower oil [mean difference -0.56 (95\% CI -1.20 to 0.08)] [30]. A study done by Kien 2014 also showed small difference for changes in body weight for men [mean difference 0.01 (95\% CI -0.91 to 0.93$)]$ and women [0.01 (95\% CI -0.92 to 0.93 )] respectively [31]. Both studies (Iggman 2014, Kien 2014) showed a difference between the group receiving the palm oil and sunflower oil [standard mean difference -0.28 (95\% CI -0.74 to 0.18 )] with low quality of evidence, downgraded for unclear risk of bias and small single study as shown in Figure 6 and Table A4.

\subsubsection{Analysis 3}

Based on one study (Kien 2005) there was no difference in BMI changes for both

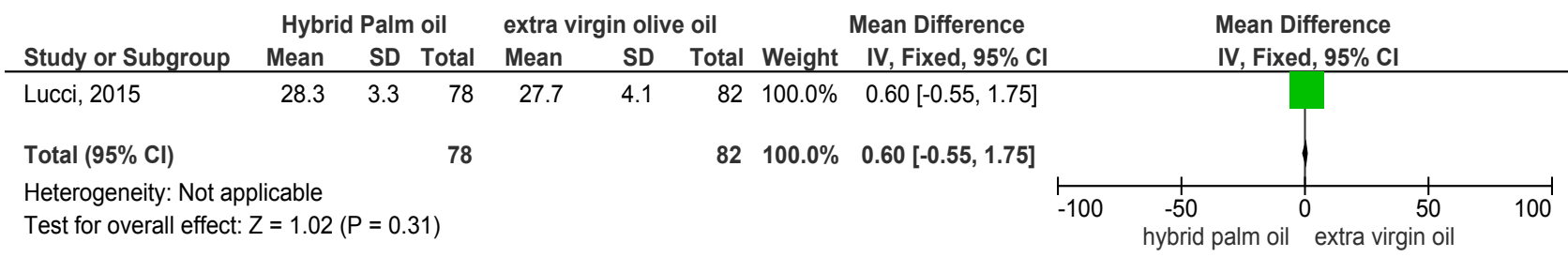

Figure 5. The effect of hybrid palm oil versus extra virgin olive oil on BMI.

$$
\text { Palm oil sunflower oil Std. Mean Difference }
$$

Study or Subgroup Mean SD Total Mean SD Total Weight IV, Random, $95 \% \mathrm{Cl}$

\begin{tabular}{lllllllll}
\hline 6.1.1 Compared group: sunflower oil predominant: both men and women \\
Iggman 2014 & 63.5 & 6.6 & 20 & 67.7 & 8.1 & 19 & $50.9 \%$ & $-0.56[-1.20,0.08]$ \\
Subtotal $(95 \% \mathrm{Cl})$ & & & 20 & & & 19 & $50.9 \%$ & $-0.56[-1.20,0.08]$
\end{tabular}

Heterogeneity: Not applicable

Test for overall effect: $Z=1.71(P=0.09)$

6.1.2 Compared group: sunflower oil mixture: men

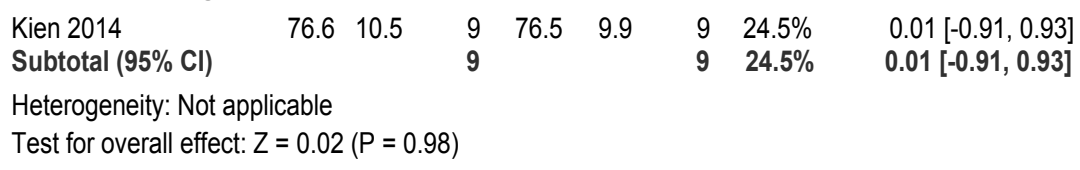

6.1.3 Compared group: sunflower oil mixture: women

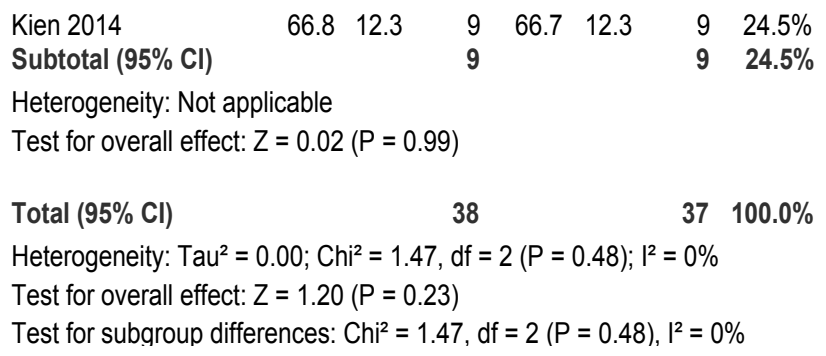

Figure 6. The effect of palm oil versus sunflower oil on body weight.
Std. Mean Difference IV, Random, 95\% Cl 
men and women who received palm oil and sunflower oil [mean difference -0.20 (95\% CI -2.01 to 1.61)] [29]. Based on another study (Kien 2014), analysis for men [mean difference 0.00 (95\% CI -2.22 to 2.22)] and women [mean difference 0.10 (95\% CI -3.50 to 3.70)] showed no difference for changes in BMI for the group receiving palm oil and sunflower oil [31]. Based on both studies (Kien 2005, Kien 2014) there was no difference in changes in BMI [standard mean difference -0.09 (95\% CI -1.40 to 1.21 )] with low-quality evidence downgrade for unclear risk of bias and small single study as shown in Figure 7 and Table A4 [29] [31].

\subsubsection{Analysis 4}

Study by Tholstrup (2011) as shown in Figure 8 revealed there was no difference in body weight changes between the groups that received palm oil and olive oil [mean difference $-0.30,95 \%$ CI (4.56 to 3.96)] with low quality of evidence, downgraded for unclear and high risk of bias and a single small study with wide CI (Table A2) [28].

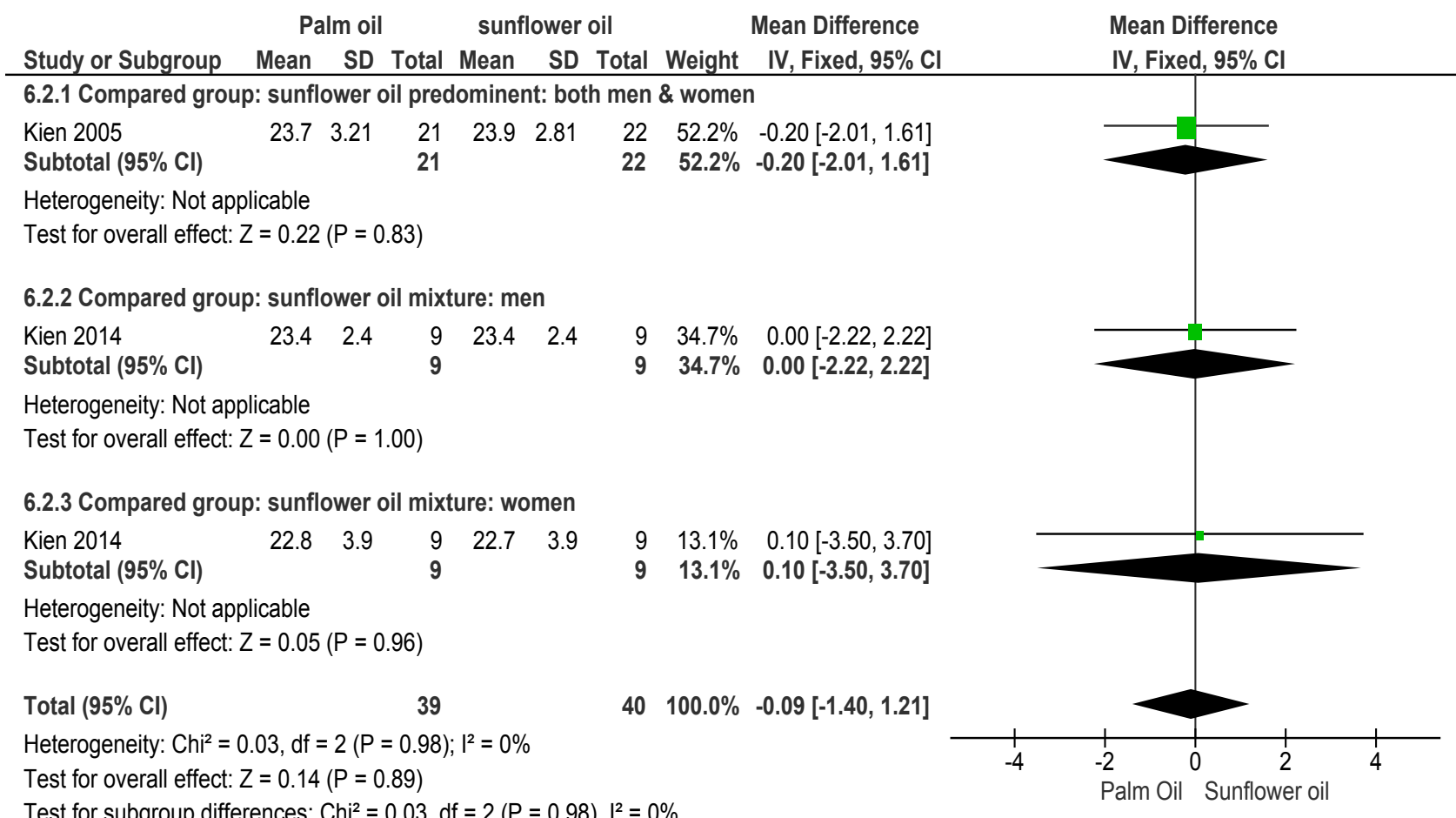

Figure 7. The effect of palm oil versus sunflower oil on BMI.

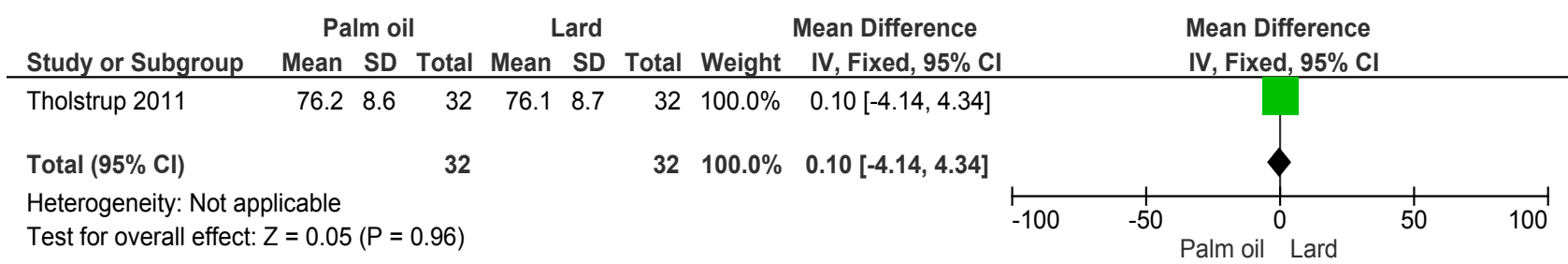

Figure 8 . The effects of palm oil vs olive oil on body weight. 


\subsubsection{Analysis 5}

Further study by Tholstrup 2011 showed there was no difference in body weight changes between the groups that received palm oil versus lard [mean difference 0.1 (95\% CI; 4.14 to 4.34)] with low quality evidence (Figure 9), downgraded for unclear risk and high of bias and single small study with wide CI as shown in Table A3 [28].

\subsubsection{Analysis 6}

Figure 10 was based on one study with 39 participants (Iggman 2014) which showed no difference in the waist changes circumference between the group that received palm oil and sunflower oil [mean difference -3.20 , (95\% CI -6.50 to $0.10)$ ] with moderate quality of evidence, downgraded for unclear risk of bias as depicted in Table A4 [30].

\section{Discussion}

The epidemic of obesity in Malaysia is in the increasing trend and mostly affected on children [9]. These overweight children are more likely to be overweight or obese in their adulthood and therefore are at greater risk of developing heart disease, diabetes, and other chronic ailments [33].

These situations however also indicated an emerging public health issue in Asia as well as in Malaysia. Developing countries including Malaysia are going through rapid nutrition transition from a large household of healthy traditional high-fibre, low-fat, and low-calorie diet shifting toward higher consumption of calorie-dense foods containing refined carbohydrates, fats, red meats, and low fibre [1].

\subsection{Summary of Main Results}

We included five studies that evaluated body weight and BMI of the participants using palm oil. However, all studies were only represented by a small number of

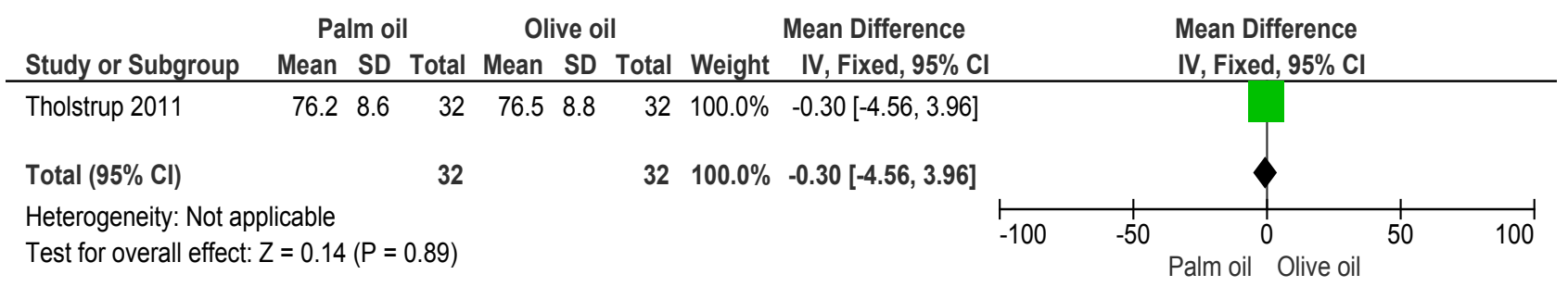

Figure 9. The effect of palm oil vs lard on body weight.

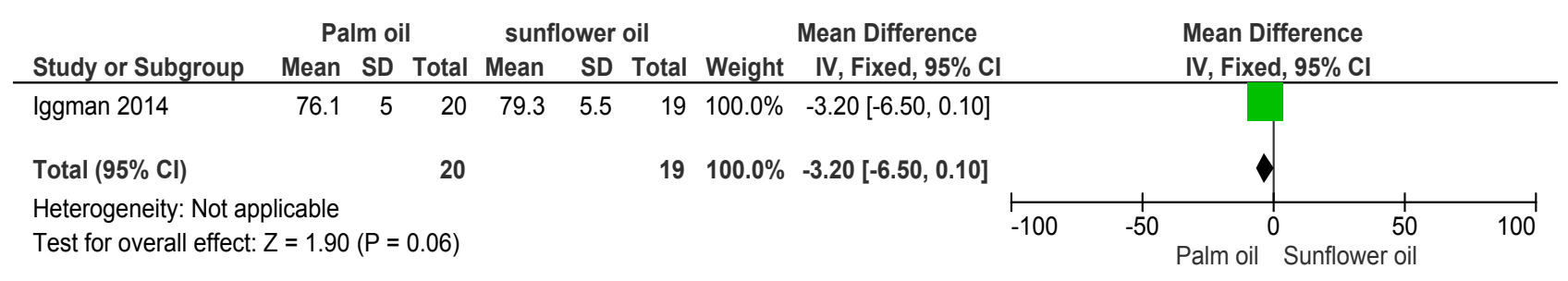

Figure 10. The effect of palm oil vs sunflower oil on waist circumference. 
participants. Overall, the effect of palm oil on BMI or body weight has not been shown to achieve statistically significant association.

There is insufficient evidence to relate the association between dietary palm oil intake and obesity. There are no clear differences between palm oil and its comparators across all outcomes.

\subsection{Overall Completeness and Applicability of Evidence}

Through a comprehensive search strategy, five studies that matched our selection criteria in terms of population, intervention, comparison and outcomes. A total of 292 participants were assessed. We believe the studies gathered in this review, although small in number, represented the best available evidence to answer the question that we posed in conducting this review. Two studies were conducted in the US and another three studies in Sweden, Denmark and Colombia. These studies could limit the applicability of the findings to other parts of the world since we didn't have any studies that represented Asia. We were unable to undertake any subgroup analyses to further determine the applicability of the findings due to insufficient data.

\subsection{Quality of the Evidence}

There was overall low-quality evidence provided by a small number of studies. The five included studies had low to high risk of bias in most domains except blinding, but the quality of evidence was downgraded by wide $95 \% \mathrm{CI}$ in the estimates (see Appendix 2).

\subsection{Potential Biases in the Review Process}

We performed a comprehensive search from multiple databases with independent screening, selection and assessment of eligible studies. The main downgrading factor was imprecision, as most outcomes were contributed by single study.

\subsection{Agreements and Disagreements with Other Studies or Reviews}

Our findings are consistent with a published article by Mancini et al. that covered palm oil as the most widely used vegetable oil in the world [15]. The study stated that no clear evidence has been provided to unequivocally demonstrate the association of palm oil consumption and increase in cardiovascular risk. However, to date, there was no study done directly for effect of dietary palm oil on obesity or adipose tissue cellularity in human.

\section{Conclusions}

There is a paucity of studies that compared the association of dietary palm oil intake and obesity, hence limiting the conclusions that we can reach. From the evidence gathered, it appeared unwarranted for any clear conclusion regarding the role of palm oil in contributing to obesity. 


\section{Implications for Research}

Other than insufficient research on this topic, this review has identified several issues in the included studies that should be considered by researchers undertaking future studies. Firstly, allocation concealment and blinding of participants and personnel were unclear, and this could have affected the reporting of subjective but clinically important outcomes such as weight reduction or body mass index. Future research should clearly emphasize on the method of randomization by using computerised randomization technique if possible. More focus should be given to the methods and selective reporting should be avoided by stating all the outcomes of interest and how were they measured. Further research is needed especially those using pure dietary palm oil versus comparator instead of using mixed palm oil vs comparators, designed in a manner that reflects actual palm oil intake in the population, and incorporating long-term measure of weight change as well as incidence of obesity or overweight as key outcomes. Future research should include key outcomes such as reduction in body weight or measurement of adipose tissues as well as body mass index or waist circumference.

\section{Acknowledgements}

We would like to thank the Director General of Health, Ministry of Health, Malaysia for permission to publish this review. Our appreciation goes to Professor Dr Lai Nai Ming, Malaysian Cochrane Trainer for his continuous guidance in developing this review.

\section{Conflicts of Interest}

The authors declare no conflicts of interest regarding the publication of this paper.

\section{References}

[1] Gregg, E.W. and Shaw, J.E. (2017) Health Effects of Overweight and Obesity in 195 Countries over 25 Years. The New England Journal of Medicine, 377, 13-27. https://doi.org/10.1056/NEJMe1706095

[2] Kelly, T., Yang, W., Chen, C.-S., Reynolds, K. and He, J. (2008) Global Burden of Obesity in 2005 and Projections to 2030. International Journal of Obesity, 32, 1431-1437. https://doi.org/10.1038/ijo.2008.102

[3] Ofei, F. (2005) Obesity-A Preventable Disease. Ghana Medical Journal, 39, 98-101.

[4] WHO (2015) Global Health Observatory (GHO) Data. http://wwwwhoint/gho/tb/en

[5] Snodgrass, S.J., Guest, M., Kable, A.K., James, C., Ashby, S.E., Plotnikoff, R.C. and Collins, C.E. (2016) Weight Management Advice for Clients with Overweight or Obesity: Allied Health Professional Survey. Healthcare, 4, pii: E85.

[6] Brown, C.D., Higgins, M., Donato, K.A., et al. (2000) Body Mass Index and the Prevalence of Hypertension and Dyslipidemia. Obesity Research, 8, 605-619. https://doi.org/10.1038/oby.2000.79 
[7] Murase, T., Mizuno, T., Omachi, T., Onizawa, K., Komine, Y., Kondo, H., Hase, T. and Tokimitsu, I. (2001) Dietary Diacylglycerol Suppresses High Fat and High Sucrose Diet-Induced Body Fat Accumulation in C57BL/6J Mice. The Journal of Lipid Research, 42, 372-378.

[8] Yusuf, S., Hawken, S., Ounpuu, S., Bautista, L., Franzosi, M.G., Commerford, P., Lang, C.C., Rumboldt, Z., Onen, C.L. and Lisheng, L. (2005) Obesity and the Risk of Myocardial Infarction in 27000 Participants from 52 Countries: A Case-Control Study. The Lancet, 366, 1640-1649. https://doi.org/10.1016/S0140-6736(05)67663-5

[9] Malaysian National Health and Morbidity Survey (2015) Vol. II: Non-Communicable Diseases, Risk Factors and Other Health Problems. Ministry of Health, Malaysia.

[10] Ponnampalam, E.N., Lewandowski, P., Nesaratnam, K., Dunshea, F.R. and Gill, H. (2011) Differential Effects of Natural Palm Oil, Chemically- and EnzymaticallyModified Palm Oil on Weight Gain, Blood Lipid Metabolites and Fat Deposition in a Pediatric Pig Model. Nutrition Journal, 10, 53. https://doi.org/10.1186/1475-2891-10-53

[11] Hu, F.B., Stampfer, M.J., Manson, J.E., Ascherio, A., Colditz, G.A., Speizer, F.E., Hennekens, H. and Willett, W.C. (1999) Dietary Saturated Fats and Their Food Sources in Relation to the Risk of Coronary Heart Disease in Women. The American Journal of Clinical Nutrition, 70, 1001-1008. https://doi.org/10.1093/ajcn/70.6.1001

[12] Katan, M.B., Zock, P.L. and Mensink, R.P. (1995) Dietary Oils, Serum Lipoproteins, and Coronary Heart Disease. The American Journal of Clinical Nutrition, 61, 1368-1373. https://doi.org/10.1093/ajcn/61.6.1368S

[13] Koushki, M., Nahidi, M. and Cheraghali, F. (2015) Physico-Chemical Properties, Fatty Acid Profile and Nutrition in Palm Oil. Journal of Paramedical Sciences, 6, 117-134.

[14] Chong, Y. and Ng, T. (1991) Effects of Palm Oil on Cardiovascular Risk. Medical Journal of Malaysia, 46, 41-50.

[15] Mancini, A., Imperlini, E., Nigro, E., Montagnese, C., Daniele, A., Orrù, S. and Buono, P. (2015) Biological and Nutritional Properties of Palm Oil and Palmitic Acid: Effects on Health. Molecules, 20, 17339-17361.

https://doi.org/10.3390/molecules200917339

[16] Ong, A. and Goh, S. (2002) Palm Oil: A Healthful and Cost-Effective Dietary Component. Food and Nutrition Bulletin, 23, 11-22. https://doi.org/10.1177/156482650202300102

[17] Higgins, J. and Deeks, J.J. (2008) Selecting Studies and Collecting Data. In: Higgins, J.P.T. and Green, S., Eds., Cochrane Handbook for Systematic Reviews of Interventions: Cochrane Book Series, The Cochrane Collaboration, 151-185.

https://doi.org/10.1002/9780470712184.ch7

[18] Vandenbroucke, J.P., von Elm, E., Altman, D.G., Gotzsche, P.C., Mulrow, C.D., Pocock, S.J., Poole, C., Schlesselman, J.J. and Egger, M. (2007) Strengthening the Reporting of Observational Studies in Epidemiology (STROBE): Explanation and Elaboration. Epidemiology, 18, 805-835. https://doi.org/10.1097/EDE.0b013e3181577511

[19] Moher, D., Liberati, A., Tetzlaff, J., Altman, D.G. and Group, P. (2009) Preferred Reporting Items for Systematic Reviews and Meta-Analyses: The PRISMA Statement. PLoS Medicine, 6, e1000097. https://doi.org/10.1371/journal.pmed.1000097

[20] WHO (2017) Health Topic Obesity. http://www.who.int/topics/obesity/en/ 
[21] Schünemann, H.J., Oxman, A.D., Brozek, J., Glasziou, P., Bossuyt, P., Chang, S., Muti, P., Jaeschke, R. and Guyatt, G.H. (2008) GRADE: Assessing the Quality of Evidence for Diagnostic Recommendations. Annals of Internal Medicine, 149, JC6-2. https://doi.org/10.7326/0003-4819-149-12-200812160-02002

[22] The Nordic Cochrane Centre (2013) Review Manager 5.3. The Nordic Cochrane Centre, The Cochrane Collaboration, Copenhagen.

[23] Deeks, J., Higgins, J., Altman, D. and Green, S. (2011) Cochrane Handbook for Systematic Reviews of Interventions Version 5.1.0 (Updated March 2011). The Cochrane Collaboration.

[24] Deeks, J.J., Higgins, J. and Altman, D.G. (2008) Analysing Data and Undertaking Meta-Analyses. In: Higgins, J.P.T. and Green, S., Eds., Cochrane Handbook for Systematic Reviews of Interventions. Cochrane Book Series, The Cochrane Collaboration, 243-296. https://doi.org/10.1002/9780470712184.ch9

[25] Higgins, J.P.T. and Green, S., Eds., (2011) Chapter 7: Selecting Studies and Collecting Data. Cochrane Handbook of Systematic Reviews of Interventions, Version 5.1.0. The Cochrane Collaboration. www.cochrane-handbook.org

[26] Schünemann, H.J., Oxman, A.D., Higgins, J.P., Vist, G.E., Glasziou, P. and Guyatt, G.H. (2008) Presenting Results and "Summary of Findings" Tables. In: Higgins, J.P.T. and Green, S., Eds., Cochrane Handbook for Systematic Reviews of Interventions. Cochrane Book Series, The Cochrane Collaboration, Chapter 11.

[27] GRADEpro (2008) Version 3.2 for Windows. Cochrane IMS.

[28] Tholstrup, T., Hjerpsted, J. and Raff, M. (2011) Palm Olein Increases Plasma Cholesterol Moderately Compared with Olive Oil in Healthy Individuals. The American Journal of Clinical Nutrition, 94, 1426-1432. https://doi.org/10.3945/ajcn.111.018846

[29] Kien, C.L., Bunn, J.Y. and Ugrasbul, F. (2005) Increasing Dietary Palmitic Acid Decreases Fat Oxidation and Daily Energy Expenditure. The American Journal of Clinical Nutrition, 82, 320-326. https://doi.org/10.1093/ajcn/82.2.320

[30] Iggman, D., Rosqvist, F., Larsson, A., Ärnlöv, J., Beckman, L., Rudling, M. and Risérus, U. (2014) Role of Dietary Fats in Modulating Cardiometabolic Risk during Moderate Weight Gain: A Randomized Double-Blind Overfeeding Trial (LIPOGAIN Study). Journal of the American Heart Association, 3, e001095. https://doi.org/10.1161/JAHA.114.001095

[31] Kien, C.L., Bunn, J.Y., Stevens, R., Bain, J., Ikayeva, O., Crain, K., Koves, T.R. and Muoio, D.M. (2014) Dietary Intake of Palmitate and Oleate Has Broad Impact on Systemic and Tissue Lipid Profiles in Humans. The American Journal of Clinical Nutrition, 99, 436-445. https://doi.org/10.3945/ajcn.113.070557

[32] Lucci, P., Borrero, M., Ruiz, A., Pacetti, D., Frega, N., Diez, O., Ojeda, M., Gagliardi, R., Parra, L. and Angel, M. (2016) Palm Oil and Cardiovascular Disease: A Randomized Trial of the Effects of Hybrid Palm Oil Supplementation on Human Plasma Lipid Patterns. Food and Function, 7, 347-354.

https://doi.org/10.1039/C5FO01083G

[33] Pell, C., Allotey, P., Evans, N., Hardon, A., Imelda, J.D., Soyiri, I. and Reidpath, D.D. (2016) Coming of Age, Becoming Obese: A Cross-Sectional Analysis of Obesity among Adolescents and Young Adults in Malaysia. BMC Public Health, 16, 1082. https://doi.org/10.1186/s12889-016-3746-x 


\section{Appendix 1: Medline Search Strategy}

\begin{tabular}{|c|c|}
\hline ID & SEARCH \\
\hline \#1 & palm oil (Word variations have been searched) \\
\hline \#2 & palm olein (Word variations have been searched) \\
\hline \#3 & palm stearin (Word variations have been searched) \\
\hline \#4 & interesterified palm oil (Word variations have been searched) \\
\hline \#5 & oleic acid (Word variations have been searched) \\
\hline \#6 & linoleic acid (Word variations have been searched) \\
\hline \#7 & red palm oil (Word variations have been searched) \\
\hline \#8 & palmitic acid (Word variations have been searched) \\
\hline \#9 & lauric acid (Word variations have been searched) \\
\hline \#10 & MeSH descriptor: [Lauric Acids] explode all trees \\
\hline \#11 & myristic acid (Word variations have been searched) \\
\hline \#12 & palm kernel oil (Word variations have been searched) \\
\hline \#13 & african oil palm (Word variations have been searched) \\
\hline \#14 & $\# 1$ or $\# 2$ or $\# 3$ or $\# 4$ or $\# 5$ or $\# 6$ or $\# 7$ or $\# 8$ or $\# 9$ or $\# 10$ or $\# 11$ or $\# 12$ \\
\hline \#15 & or \#13Overweight (Word variations have been searched) \\
\hline \#16 & Obes (Word variations have been searched) \\
\hline \#17 & Pre obese (Word variations have been searched) \\
\hline \#18 & Body weight (Word variations have been searched) \\
\hline 19 & Body mass index (Word variations have been searched) \\
\hline \#20 & Waist hip ratio (Word variations have been searched) \\
\hline 21 & Waist circumference (Word variations have been searched) \\
\hline 22 & Body weight (Word variations have been searched) \\
\hline 23 & Weight gain (Word variations have been searched) \\
\hline \#24 & Fat (Word variations have been searched) \\
\hline \#25 & Adiposity (Word variations have been searched) \\
\hline \#26 & Anthropometry (Word variations have been searched) \\
\hline \#27 & \#15 OR \#16 OR \#17 OR \#18 OR \#19 OR \#20 OR \#21 OR \#22 OR \#23 OR \\
\hline \#28 & \#obesity24 OR \# 25 OR \#26 \\
\hline \#29 & \#14 AND \#27 AND \#28 \\
\hline
\end{tabular}




\section{Appendix 2: Summary of Findings Tables}

Effect of Intervention

Table A1. Hybrid palm oil versus virgin olive oil.

Summary of findings:

Hybrid palm oil compared to extra virgin olive oil

Patient or population: healthy adults

Setting: Columbia

Intervention: hybrid palm oil

Comparison: extra virgin olive oil

\begin{tabular}{|c|c|c|c|c|c|c|}
\hline & \multicolumn{2}{|c|}{$\begin{array}{l}\text { Anticipated absolute effects } \\
(95 \% \mathrm{CI})\end{array}$} & \multirow{2}{*}{$\begin{array}{l}\text { Relative } \\
\text { effect } \\
(95 \% \mathrm{CI})\end{array}$} & \multirow{2}{*}{$\begin{array}{l}\text { № of } \\
\text { participants } \\
\text { (studies) }\end{array}$} & \multirow{2}{*}{$\begin{array}{l}\text { Quality of the } \\
\text { evidence } \\
\text { (GRADE) }\end{array}$} & \multirow{2}{*}{ Comments } \\
\hline & $\begin{array}{l}\text { Risk with extra } \\
\text { virgin olive oil }\end{array}$ & $\begin{array}{c}\text { Risk with } \\
\text { hybrid palm oil }\end{array}$ & & & & \\
\hline \multicolumn{3}{|c|}{$\begin{array}{l}\text { The mean BMI, The mean BMI, was } \\
\text { BMI, } 27.7 \text { in the intervention group was } \\
0.6 \text { higher ( } 0.55 \text { lower to } 1.75 \text { higher) }\end{array}$} & 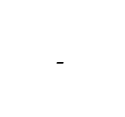 & $\begin{array}{c}160 \\
(1 \mathrm{RCT})\end{array}$ & $\begin{array}{l}\oplus \oplus \circ \bigcirc \\
\text { LOW }^{\mathrm{a}, \mathrm{b}}\end{array}$ & \\
\hline
\end{tabular}

${ }^{*}$ The risk in the intervention group (and its $95 \%$ confidence interval) is based on the assumed risk in the comparison group and the relative effect of the intervention (and its 95\% CI).

CI: Confidence interval; MD: Mean difference

\section{GRADE Working Group grades of evidence}

High quality: We are very confident that the true effect lies close to that of the estimate of the effect

Moderate quality: We are moderately confident in the effect estimate: The true effect is likely to be close to the estimate of the effect, but there is a possibility that it is substantially different

Low quality: Our confidence in the effect estimate is limited: The true effect may be substantially different from the estimate of the effect

Very low quality: We have very little confidence in the effect estimate: The true effect is likely to be substantially different from the estimate of effect

a. The study has unclear risks of selection, performance and detection biases

b. Single study with wide $95 \%$ CI 
Table A2. Palm oil versus olive oil.

Summary of findings:

Palm oil compared to olive oil

Patient or population: Healthy adults (men \& women)

Setting: Denmark

Intervention: Palm oil

Comparison: Olive oil

\begin{tabular}{|c|c|c|c|c|c|c|}
\hline \multirow{2}{*}{ Outcomes } & \multicolumn{2}{|c|}{$\begin{array}{l}\text { Anticipated absolute effects } \\
\qquad(95 \% \mathrm{CI})\end{array}$} & \multirow{2}{*}{$\begin{array}{c}\text { Relative } \\
\text { effect } \\
(95 \% \mathrm{CI})\end{array}$} & \multirow{2}{*}{$\begin{array}{c}\text { № of } \\
\text { participants } \\
\text { (studies) }\end{array}$} & \multirow{2}{*}{$\begin{array}{c}\text { Quality of the } \\
\text { evidence } \\
\text { (GRADE) }\end{array}$} & \multirow{2}{*}{ Comments } \\
\hline & $\begin{array}{c}\text { Risk with } \\
\text { olive oil }\end{array}$ & $\begin{array}{l}\text { Risk with } \\
\text { palm oil }\end{array}$ & & & & \\
\hline BMI, & $\begin{array}{l}\text { The mean } \\
\text { mean body we } \\
\text { the intervent } \\
\text { lower }(4.56 \text { lo }\end{array}$ & $\begin{array}{l}\text { weight, The } \\
\text { was } 76.2 \mathrm{~kg} \text {, in } \\
\text { group was } 0.3 \\
\text { to } 3.96 \text { higher) }\end{array}$ & - & $\begin{array}{c}64 \\
(1 \mathrm{RCT})\end{array}$ & $\begin{array}{l}\bigoplus \bigoplus \bigcirc \bigcirc \\
\text { LOW }^{\mathrm{a}, \mathrm{b}}\end{array}$ & \\
\hline
\end{tabular}

${ }^{*}$ The risk in the intervention group (and its 95\% confidence interval) is based on the assumed risk in the comparison group and the relative effect of the intervention (and its 95\% CI).

CI: Confidence interval; MD: Mean difference

\section{GRADE Working Group grades of evidence}

High quality: We are very confident that the true effect lies close to that of the estimate of the effect

Moderate quality: We are moderately confident in the effect estimate: The true effect is likely to be close to the estimate of the effect, but there is a possibility that it is substantially different

Low quality: Our confidence in the effect estimate is limited: The true effect may be substantially different from the estimate of the effect

Very low quality: We have very little confidence in the effect estimate: The true effect is likely to be substantially different from the estimate of effect

a. The study has unclear risks of selection and performance biases and high risk bias for incomplete outcome data

b. Single study with wide $95 \%$ CI 
Table A3. Palm oil versus lard.

Summary of findings:

\section{Palm oil compared to lard}

Patient or population: Healthy adults (men \& women)

Setting: Denmark

Intervention: Palm oil

Comparison: Lard

\begin{tabular}{|c|c|c|c|c|c|c|}
\hline \multirow{2}{*}{ Outcomes } & \multicolumn{2}{|c|}{$\begin{array}{l}\text { Anticipated absolute effects } \\
\qquad(95 \% \mathrm{CI})\end{array}$} & \multirow{2}{*}{$\begin{array}{c}\text { Relative } \\
\text { effect } \\
(95 \% \mathrm{CI})\end{array}$} & \multirow{2}{*}{$\begin{array}{c}\text { № of } \\
\text { participants } \\
\text { (studies) }\end{array}$} & \multirow{2}{*}{$\begin{array}{c}\text { Quality of the } \\
\text { evidence } \\
\text { (GRADE) }\end{array}$} & \multirow{2}{*}{ Comments } \\
\hline & $\begin{array}{c}\text { Risk with } \\
\text { olive oil }\end{array}$ & $\begin{array}{l}\text { Risk with } \\
\text { palm oil }\end{array}$ & & & & \\
\hline BMI, & $\begin{array}{r}\text { The mean } \\
\text { mean body w } \\
\text { the interven } \\
\text { higher (4.14 } 1\end{array}$ & $\begin{array}{l}\text { weight, The } \\
\text { was } 76.2 \mathrm{~kg} \text {, in } \\
\text { group was } 0.1 \\
\text { to } 4.34 \text { higher) }\end{array}$ & 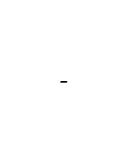 & $\begin{array}{c}64 \\
(1 \mathrm{RCT})\end{array}$ & $\begin{array}{l}\oplus \oplus \bigcirc \bigcirc \\
\text { LOW }^{\mathrm{a}, \mathrm{b}}\end{array}$ & \\
\hline
\end{tabular}

${ }^{*}$ The risk in the intervention group (and its 95\% confidence interval) is based on the assumed risk in the comparison group and the relative effect of the intervention (and its 95\% CI).

CI: Confidence interval; MD: Mean difference

\section{GRADE Working Group grades of evidence}

High quality: We are very confident that the true effect lies close to that of the estimate of the effect

Moderate quality: We are moderately confident in the effect estimate: The true effect is likely to be close to the estimate of the effect, but there is a possibility that it is substantially different

Low quality: Our confidence in the effect estimate is limited: The true effect may be substantially different from the estimate of the effect

Very low quality: We have very little confidence in the effect estimate: The true effect is likely to be substantially different from the estimate of effect

a. The study has unclear risks of selection and performance biases and high risk for incomplete outcome data

b. Single study with wide $95 \%$ CI 
Table A4. Palm oil versus sunflower oil.

Summary of findings:

Palm oil compared to sunflower oil

Patient or population: Healthy adults (men \& women)

Setting: United States \& Sweden

Intervention: Palm oil

\begin{tabular}{|c|c|c|c|c|c|c|}
\hline \multirow{2}{*}{ Outcomes } & \multicolumn{2}{|c|}{ Anticipated absolute effects (95\% CI) } & \multirow{2}{*}{$\begin{array}{l}\text { Relatives } \\
\text { effects } \\
(95 \% \mathrm{CI})\end{array}$} & \multirow{2}{*}{$\begin{array}{l}\text { No or } \\
\text { Participants } \\
\text { (studies) }\end{array}$} & \multirow{2}{*}{$\begin{array}{l}\text { Quality of } \\
\text { evidence } \\
\text { (GRADE) }\end{array}$} & \multirow{2}{*}{ Comments } \\
\hline & Risk with Sunflower oil & Risk with palm oil & & & & \\
\hline $\begin{array}{l}\text { Change in weight } \\
\text { compared group: } \\
\text { sunflower oil mixture: } \\
\text { men }\end{array}$ & $\begin{array}{l}\text { The mean change in weight } \\
\text { compared group: sunflower } \\
\text { oil predominant, both men } \\
\text { and women was } 1.44 \mathrm{~kg}\end{array}$ & $\begin{array}{l}\text { The mean change in weight } \\
\text { compared group: sunflower oil } \\
\text { predominant, both men and } \\
\text { women was } 0.04 \mathrm{~kg} \text { higher ( } 0.65 \\
\text { lower to } 0.73 \text { higher) }\end{array}$ & - & 39 (1 RCT) & $\begin{array}{l}\oplus \oplus \oplus \circ \\
\text { moderate }^{*}\end{array}$ & \\
\hline $\begin{array}{l}\text { Body weight- } \\
\text { compared group: } \\
\text { sunflower oil mixture: } \\
\text { men }\end{array}$ & $\begin{array}{l}\text { The mean body weight- } \\
\text { compared group: sunflower } \\
\text { oil mixture: men was } 76.5 \mathrm{~kg}\end{array}$ & $\begin{array}{l}\text { The mean body weight- } \\
\text { compared group: sunflower oil } \\
\text { mixture: men in the intervention } \\
\text { group was } 0.1 \mathrm{~kg} \text { higher ( } 9.33 \text { lower } \\
\text { to } 9.53 \text { higher) }\end{array}$ & - & 18 (1 RCT) & $\begin{array}{l}\oplus \oplus \circ \bigcirc \\
\mathrm{LOW}^{\mathrm{a}, \mathrm{b}}\end{array}$ & \\
\hline $\begin{array}{l}\text { Body weight-compared } \\
\text { group: sunflower oil } \\
\text { mixture: women }\end{array}$ & $\begin{array}{l}\text { The mean body weight- } \\
\text { compared group: sunflower } \\
\text { oil mixture: women was } \\
66.7 \mathrm{~kg}\end{array}$ & $\begin{array}{l}\text { The mean body weight- } \\
\text { compared group: sunflower oil } \\
\text { mixture: women in the } \\
\text { intervention group was } 0.1 \mathrm{~kg} \\
\text { higher ( } 11.26 \text { lower to } 11.46 \\
\text { higher) }\end{array}$ & - & $18(1 \mathrm{RCT})$ & $\begin{array}{l}\oplus \oplus \bigcirc \bigcirc \\
\mathrm{LOW}^{\mathrm{a}, \mathrm{b}}\end{array}$ & \\
\hline BMI & The mean BMI was 23.4 & $\begin{array}{l}\text { The mean BMI in the intervention } \\
\text { group was } 0.09 \text { lower ( } 1.4 \text { lower to } \\
1.21 \text { higher) }\end{array}$ & - & 79 (2 RCT) & $\begin{array}{l}\oplus \bigoplus \bigcirc \bigcirc \\
\text { LOW }^{c, d}\end{array}$ & \\
\hline Waist circumference & $\begin{array}{l}\text { The mean waist } \\
\text { circumference was } 79.3 \mathrm{~cm}\end{array}$ & $\begin{array}{l}\text { The mean waist circumference in } \\
\text { the intervention group was } 3.2 \mathrm{~cm} \\
\text { lower ( } 6.5 \text { lower to } 0.1 \text { higher) }\end{array}$ & - & 39 (1 RCT) & $\begin{array}{l}\oplus \oplus \oplus \circ \\
\text { moderate }^{*}\end{array}$ & \\
\hline
\end{tabular}

${ }^{*}$ The risk in the intervention group (and its 95\% confidence interval) is based on the assumed risk in the comparison group and the relative effect of the intervention (and its 95\% CI).

CI: Confidence interval; MD: Mean difference

\section{GRADE Working Group grades of evidence}

High quality: We are very confident that the true effect lies close to that of the estimate of the effect

Moderate quality: We are moderately confident in the effect estimate: The true effect is likely to be close to the estimate of the effect, but there is a possibil- 
ity that it is substantially different

Low quality: Our confidence in the effect estimate is limited: The true effect may be substantially different from the estimate of the effect

Very low quality: We have very little confidence in the effect estimate: The true effect is likely to be substantially different from the estimate of effect

a. A single small study with wide $95 \%$ CI

b. The single included study had high risk of selection bias and unclear risks in most other domains

c. The included studies had either high risk in selection or detection bias and unclear risks in all other domains

d. There are only two small studies with wide $95 \%$ CI for this outcome 